\title{
Solidago canadensis as a bioaccumulator and phytoremediator of $\mathrm{Pb}$ and $\mathrm{Zn}$
}

\author{
Aleksandra Bielecka ${ }^{1}$ E Elżbieta Królak ${ }^{1}$ (D) \\ Received: 17 April 2019 / Accepted: 9 October 2019 /Published online: 19 November 2019 \\ (C) The Author(s) 2019
}

\begin{abstract}
Canadian goldenrod (Solidago canadensis L.) is a plant that grows in a variety of environmental conditions. It shows high capability to spread in various habitats, including fallow lands and brownfield land. The research aimed at analyzing the content of $\mathrm{Pb}$ and $\mathrm{Zn}$ in the underground (roots, rhizomes) and aboveground parts (stems, leaves, inflorences) of Solidago canadensis (SC) originating from two locations that are clearly different in terms of metal content in soil. Statistically significant differences were determined in the content of $\mathrm{Pb}$ and $\mathrm{Zn}$ in soil and particular morphological parts of the plant, depending on the sampling location. It has been shown that in the conditions of increased (compared with natural) $\mathrm{Pb}$ and $\mathrm{Zn}$ content in the soil, $\mathrm{SC}$ may serve as a bioaccumulator of these metals. It was determined that $\mathrm{SC}$ can be used as a phytostabilizer of $\mathrm{Pb}$ and $\mathrm{Zn}$ in soils heavily contaminated with these elements. The content of $\mathrm{Zn}$ in the aboveground parts of SC indicates that this plant can also be used for phytoextraction of soils contaminated with this metal.
\end{abstract}

Keywords Canadian goldenrod $\cdot$ Aboveground parts $\cdot$ Belowground parts $\cdot$ Soil $\cdot$ Heavy metals $\cdot$ Bioconcentration factor $(\mathrm{BCF})$. Translocation factor (TF)

\section{Introduction}

In recent years, plants of the genus Solidago (Asteraceae) have been given a relatively high level of attention in environmental studies. Goldenrods (Solidago spp.) are classified as invasive plants (Weber and Schmid 1998; Tokarska-Guzik et al. 2012). The native range of Solidago sp. is North America (Weber and Jacobs 2005). In the last century, Solidago species have spread throughout almost all of Europe (Guzikowa and Maycock 1986; Weber 1997, 2000) and Asia (Lu et al. 2007; Semple and Rao 2017). They also occur in Africa (Cheek and Semple 2016) and Australia (Semple and Uesugi 2017). The ability of Solidago canadensis L. (SC) to quickly colonize new areas results from the strong reproductive capacity of its underground parts, fast spreading and germination of seeds

Highlights Canadian goldenrod as a phytostabilizator of $\mathrm{Pb}$ and $\mathrm{Zn}$ and phytoextractor of $\mathrm{Zn}$

Responsible editor: Elena Maestri

Elżbieta Królak

elzbieta.krolak@uph.edu.pl

1 Faculty of Natural Sciences, Siedlce University of Natural Sciences and Humanities, Prusa 14, 08-110 Siedlce, Poland
(Huang and Guo 2005). The species tolerates a wide range of environmental conditions (e.g., Jin et al. 2004; Huang et al. 2007). The species forms extensive and compact patches, especially in anthropogenic sites. It occurs in abandoned cultivated fields (Szymura and Wolski 2006) as well as on industrial wastelands (Vega et al. 2004; Antonijevic et al. 2012; Patrzałek et al. 2012). Individual clones form dense clusters, composed of many ramets, depending on the age of a given clone. The roots branch out from the base of ramets and reach the minimum depth of $20 \mathrm{~cm}$ (Weber 2000). The goldenrod also produces large amounts of aboveground biomass, estimated at about $20 \mathrm{Mg}$ of fresh weight/ha in the case of $70 \%$ ground cover (Patrzałek et al. 2012). The ratio of the under- to aboveground biomass of $\mathrm{SC}$ is often between 0.25 and 0.82 (Wang et al. 2017).

Many scientific papers relate to the impact of SC on biodiversity decline (e.g., Huang and Guo 2005; Gioria and Osborne 2014; Fenesi et al. 2015; Holeksa et al. 2015). Literature, however, lacks comprehensive information on the content of metals, including $\mathrm{Pb}$ and $\mathrm{Zn}$, in particular morphological parts of the plant. Studies aimed at assessing the accumulation of heavy metals in the tissues of the plant (e.g., Vega et al. 2004; Huang et al. 2007; Yang et al. 2007a), but there is no data on the possibility of its use for phytoremediation. Due 
to the extensive underground system and its high biomass (Wang et al. 2017) and the role of rhizome as a storage organ in the plant, we have undertaken this study to assess the level of $\mathrm{Pb}$ and $\mathrm{Zn}$ accumulation in individual parts of SC occurring in two areas: agricultural and industrial.

The ability of plants to accumulate heavy metals is also used in biomonitoring of the environment (Markert et al. 2003). Biomonitoring studies including the analysis of bioaccumulation of metals in plants are also undertaken to identify species that can be used in phytoremediation (Massa et al. 2010). Plants used in phytoremediation should be capable to colonize contaminated areas and should be adaptive to edaphic conditions. They should characterize with the ease of taking heavy metals from the environment. Phytostabilization processes are connected with the reduction of bioavailability and mobility of metals. Plants used in phytostabilization, in addition to their ability to retain metals in the roots, should have an extensive root systems. Phytoextration is connected with the uptake of a contaminant by plant roots from the environment and its translocation into harvestable plant biomass. Plant features that predispose them to phytoextraction include: high metal accumulation in aboveground parts, high biomass of aboveground parts, ease of harvesting, good adaptation to environmental and climatic conditions (Laghlimi et al. 2015).

Some traits of SC, such as wide range of tolerance to physicochemical conditions, ability to colonize contaminated soils, high biomass of aboveground parts, extensive underground system, the possibility of accumulation of heavy metals, and easy collection from the environment indicate the usefulness of the plant in both biomonitoring and phytoremediation.

Biomonitoring studies using $\mathrm{SC}$ as a heavy metal accumulator are conducted to a limited extent. Few reports refer to $\mathrm{Pb}$ content in plant roots (Xiang et al. 2010; Yang et al. 2008), Pb and $\mathrm{Zn}$ content in stems, leaves and roots (Antonijevic et al. 2012). There is no complex information in the literature on the content of metals, including $\mathrm{Pb}$ and $\mathrm{Zn}$, in all individual morphological parts of the plant, including inflorescences and rhizomes.

The objective of this study was to assess the content of $\mathrm{Pb}$ and $\mathrm{Zn}$ in different fully developed morphological parts (roots, rhizomes, stems, leaves, inflorescences) of SC originating from agricultural and industrial areas, different in terms of $\mathrm{Pb}$ and $\mathrm{Zn}$ content in the soil.

The following hypotheses were put forward in the paper:

- $\mathrm{SC}$ accumulates $\mathrm{Pb}$ and $\mathrm{Zn}$ in concentrations proportional to the content of metals in soil,

- Morphological parts of SC originating from agricultural and industrial areas differ in the content of $\mathrm{Pb}$ and $\mathrm{Zn}$.

The possibility of using SC as a bioaccumulator and phytoremediator of both heavy metals was presented.

\section{Material and methods}

\section{Study area}

The research was conducted in Poland in two locations: agricultural (AA-the region of Siedlce-central-eastern Poland: $52^{\circ} 13^{\prime} 72^{\prime \prime} \mathrm{N}-52^{\circ} 74^{\prime} 25^{\prime \prime} \mathrm{N}$ and $22^{\circ} 13^{\prime} 29^{\prime \prime} \mathrm{E}-22^{\circ} 25^{\prime} 24^{\prime \prime}$ E) and industrial (IA-Olkusz-southern Poland: $50^{\circ} 15^{\prime} 83^{\prime \prime}$ $\mathrm{N}-50^{\circ} 23^{\prime} 39^{\prime \prime} \mathrm{N}$ and $19^{\circ} 26^{\prime} 50^{\prime \prime} \mathrm{E}-19^{\circ} 36^{\prime} 46^{\prime \prime} \mathrm{E}$ ) (Fig. 1). Podzolic and pseudopodzolic soils, developed on sand and sandy loam, dominate in the agricultural region. They are characterized by acid reaction, low humus content (Hoser and Pirowski 2014), and natural $\mathrm{Pb}$ and $\mathrm{Zn}$ content (Siebielec 2017).

The soil in the industrial region is characterized by high content of heavy metals. In the area, there are sites with extreme contents of $\mathrm{Pb}$ and $\mathrm{Zn}$, which results from centuries-long industrial activity involving the extraction and processing of zinc and lead ores (Gruszecka and Wdowin 2013; Kapusta et al. 2015). In the region, loamy sand rich in calcium prevails (Wach et al. 2014).

\section{Plant material}

Samples were collected from both locations in the last decade of August 2017 during intensive flowering of the Canadian goldenrod. The sites were selected at random; their choice was based on the presence of the goldenrod at an area of at least $500 \mathrm{~m}^{2}$. Twenty five sites were selected at each location. At each site, three plots with an area of $9 \mathrm{~m}^{2}(3 \times 3 \mathrm{~m})$ were selected, located at least $2 \mathrm{~m}$ from the edge of a given site and diagonally across the examined surface. The number of ramets were counted at each plot to determine the density of the goldenrod. Next, the goldenrod samples were collected from each plot, using a $40 \times 40 \mathrm{~cm}$ frame $\left(0.16 \mathrm{~m}^{2}\right)$. The aboveground (stems, leaves, inflorescences) and underground (roots and rhizomes) parts of plants were cut - the latter from a depth of up to $20 \mathrm{~cm}$. Ramets cut from the surface of $0.16 \mathrm{~m}^{2}$ were counted and used to determine the biomass of the aboveground parts of the plant per 1 ramet. The collected plants were healthy, without any sign of morphological damage. Twenty ramets were sampled for analysis from each site. Leaves, stems and inflorescences, roots, and rhizomes were isolated from each plant in the laboratory. The underground parts were carefully washed under running water and then rinsed in distilled water. The plant material was dried at a temperature of $60^{\circ} \mathrm{C}$ to a constant weight. The mass of each morphological part per ramet was calculated following the determination of dry weight. The samples were homogenized. $1 \mathrm{~g}$ subsamples were pre-mineralized in a muffle furnace at a temperature of $420{ }^{\circ} \mathrm{C}$, which was followed by microwave mineralization in $68 \%$ nitric acid (ultra-pure) and $30 \%$ hydrogen peroxide (ultra-pure) $(3: 2, \mathrm{v} / \mathrm{v})$ (Ostrowska et al. 1991). 
Three independent subsamples were prepared. Mean values of the results were used in calculations prepared for each site.

\section{Soil samples}

Four soil subsamples were collected in the field from each plot using Egner's sampling stick. A total of 12 soil subsamples were collected from each site and pooled. They were representative samples for each site. Soil samples were air-dried in the laboratory. The soil was then sieved through a sieve with a mesh diameter of $2 \mathrm{~mm}$. The representative soil subsamples were homogenized in an agate mortar, initially mineralized in a muffle furnace at a temperature of $420^{\circ} \mathrm{C}$ and, as in the case of plants, mineralized in a mixture of $\mathrm{HNO}_{3}(68 \%)$ and $\mathrm{H}_{2} \mathrm{O}_{2}$ $(30 \%)$ in a microwave mineralizer. Additionally, to determine the content of $\mathrm{N}$, the soil samples $(1 \mathrm{~g})$ were mineralized in Kjeldahl flasks in $95 \% \mathrm{H}_{2} \mathrm{SO}_{4}$ and $30 \% \mathrm{H}_{2} \mathrm{O}_{2}(3: 1, \mathrm{v} / \mathrm{v})$ (Ostrowska et al. 1991).

\section{Analysis of heavy metals content in the plant material and soil samples}

The content of lead and zinc in solutions obtained after mineralization was determined using the atomic absorption spectrometric (AAS) technique (an apparatus manufactured by Carl Zeiss Jena) and an acetylene-air flame. Standard solutions within the following ranges of concentration $\left(\mu \mathrm{g} \mathrm{ml}^{-1}\right)$ : $\mathrm{Pb}$ 0.2-3.0 and $\mathrm{Zn} 0.3-3.6$ were used for the determination of the metals. In the case of high content of metals in the samples, exceeding the concentration range of standard solutions, the examined samples were diluted. The reference material (INCP-PVTL-6) was used in the study, which was prepared and certified at the Institute of Nuclear Chemistry and Technology (Warsaw, Poland). Recoveries of lead and zinc were $104.5 \%$ and $96.7 \%$, respectively, and the accuracy of measurements expressed by the coefficient of variation was $6.7 \%$ for $\mathrm{Pb}$ and $4.9 \%$ for $\mathrm{Zn}$.

Results of the analysis of selected soil chemical parameters and the content of metals in individual morphological parts of

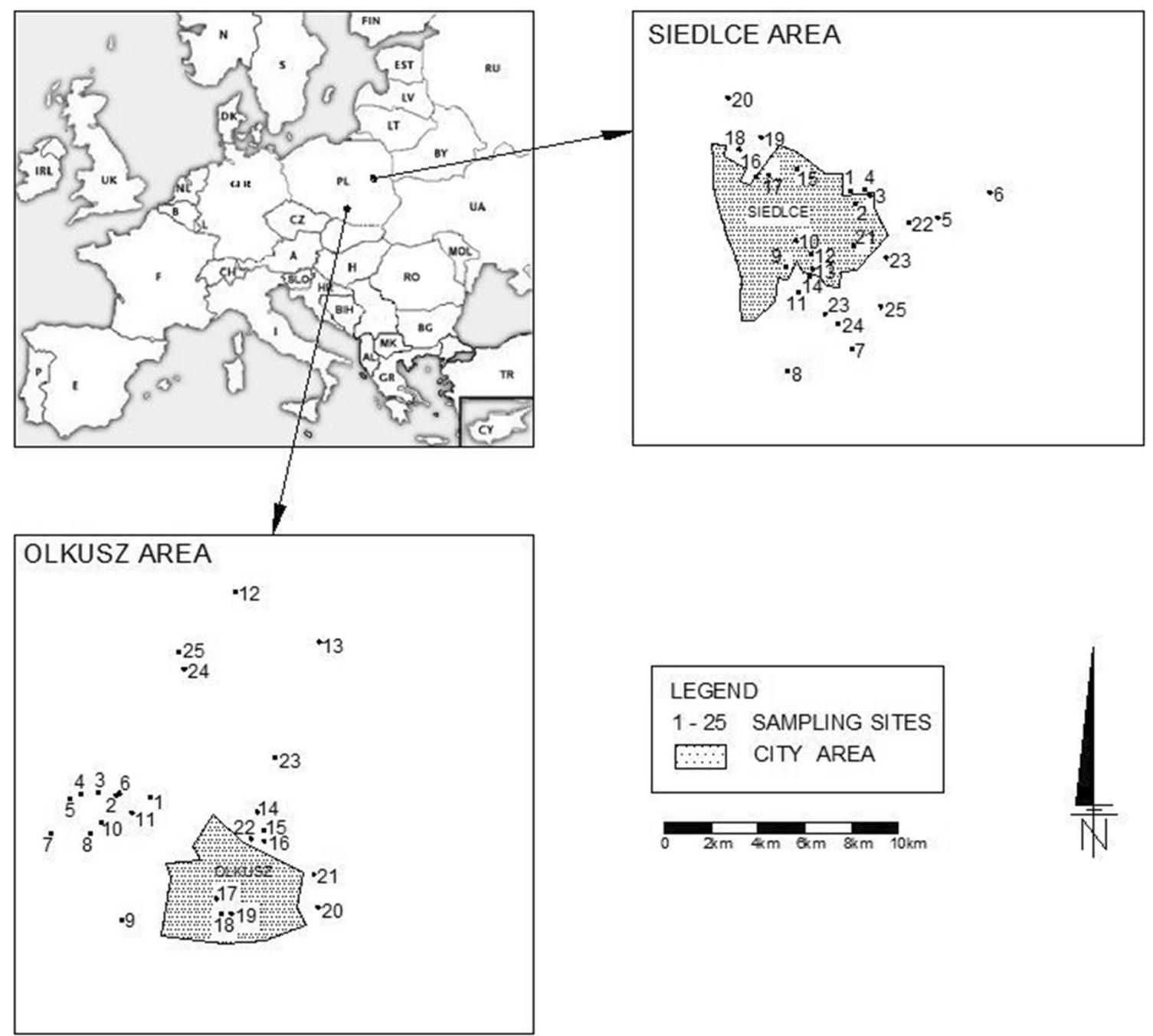

Fig. 1 Location of the study area and sampling sites (Siedlce-agricultural area AA, Olkusz-industrial area IA) 
the plant were calculated per $1 \mathrm{~g} \mathrm{DW}$ of a given sample. Bioconcentration factors $(\mathrm{BCF})$ were calculated based on the ratio of the concentration of the metal in the root and the concentration of that metal in the soil, while translocation factors (TF) were calculated as the ratio of metal concentration in rhizomes, stems, leaves, and flowers to the metal concentration in the root (Malik et al. 2010).

\section{Analysis of soil reaction, the contents of organic carbon, and nitrogen}

The soil reaction was measured in $1 \mathrm{M} \mathrm{KCl}(1: 2.5)$, the content of organic carbon was determined with the use of Tiurin's method (Ostrowska et al. 1991) and nitrogen - with the use of indophenol method (Marczenko 1979).

\section{Statistical analysis}

The normality of data was tested using the Shapiro-Wilk test and homoscedasticity with the Brown-Forsythe test. Nonparametric tests were used because of non-normal distributions of the variables and heteroscedasticity. The MannWhitney test was applied to compare soil acidity, the content of organic carbon, the content of nitrogen, and the content of $\mathrm{Pb}$ and $\mathrm{Zn}$ in the soil and in parts of the plant in both locations, while the significance of differences in the content of metals in different morphological parts of the plant and in soil samples in the same location was calculated using Kruskal-Wallis test and Dunn's post-hoc test. Spearman's correlation rank coefficients were used as a measure of the strength of the relationships between the content of $\mathrm{Pb}$ and $\mathrm{Zn}$ in the soil and in the plant parts. The similarity (based on Euclidean distance) between the study sites in terms of $\mathrm{Pb}$ and $\mathrm{Zn}$ content in the soil and SC tissues was analyzed using the clustering with Ward's linkeage method. To compare the values of the number of ramets per $1 \mathrm{~m}^{2}$ and the biomass of particular morphological parts, $t$ test was used. Statistical analyses were performed using STATISTICA 12 software.

\section{Results}

Soil samples collected in the agricultural area are characterized with lower $\mathrm{pH}$, organic carbon, and nitrogen contents compared with the samples collected in the industrial area (Table 1).

Soil samples in the selected locations were significantly different in terms of $\mathrm{Pb}$ and $\mathrm{Zn}$ content. The content of $\mathrm{Pb}$ and $\mathrm{Zn}$ in the soil samples from the industrial area described by the median value was about 10 times higher compared with the soil samples from the agricultural area (Table 2).

The accumulation of $\mathrm{Pb}$ per $1 \mathrm{~kg}$ DW in particular parts of the plant decreased in the following order: IA-root $>$ rhizome
$>$ leaves $>$ inflorescence $>$ stem and AA: root $>$ leaves $>$ rhizome $>$ inflorescence $>$ stem. The accumulation of $\mathrm{Zn}$ in specific morphological parts of the plant calculated per $1 \mathrm{~kg}$ DW varied as follows: IA: roots $>$ rhizomes $>$ leaves $>$ stems $>$ inflorescences, AA: stems $>$ leaves $>$ rhizomes $>$ roots $>$ inflorescences. The content of both metals in different morphological parts of SC collected in IA was significantly higher than in AA (Table 2).

The co-occurrence of $\mathrm{Zn}$ and $\mathrm{Pb}$ in the soil was determined in both locations. Statistically significant correlations between $\mathrm{Zn}$ content in the soil and $\mathrm{Zn}$ content in the roots, stems, leaves, and inflorescences of $\mathrm{SC}$, as well as between $\mathrm{Pb}$ content in the soil and $\mathrm{Pb}$ content in the roots, rhizomes, stems, and leaves of SC were found in the goldenrod samples from the industrial area. No similar correlations were between the content of the metals in the soil and tissues of SC harvested at the agricultural sites (Table 3 ).

The correlation analysis showed no effect of selected soil parameters ( $\mathrm{pH}$, organic carbon, and nitrogen content) on the metal content in the examined parts of SC. The only significant correlation $(p<0.01)$ between soil $\mathrm{pH}$ on $\mathrm{Pb}$ and $\mathrm{Zn}$ content was noted in soil samples from the agricultural area $\left(R_{\mathrm{S}}=0.59\right.$ and $R_{\mathrm{S}}=0.72$ respectively). A significant correlation $(p<0.05)$ was also noted between organic carbon content and $\mathrm{Pb}$ and $\mathrm{Zn}$ contents in samples taken in both locations $\left(R_{\mathrm{S}}\right.$ values in the range $0.41-0.51$ ).

Values of the $\mathrm{Pb}$ bioconcentration factor in the root/soil system as well as of the factor of $\mathrm{Pb}$ translocation from roots to other morphological parts of the plant were higher in the agricultural area than in the industrial area. Similarly, higher values of $\mathrm{Zn}$ translocation factor from roots to the rhizomes, stems, leaves, and flowers were determined in goldenrod harvested in the agricultural area (Table 4).

Cluster analysis showed a greater similarity of samples in terms of $\mathrm{Pb}$ and $\mathrm{Zn}$ content in the agricultural (Euclidean distance below 350; Fig. 2A) than in the industrial area (Euclidean distance above 8000; Fig. 2B). In the dendrogram presenting $\mathrm{Pb}$ and $\mathrm{Zn}$ contents in samples from the agricultural area (Fig. 2A), the extreme positions are occupied by sites with higher zinc (sites 1,2) and lead (sites 11,12) content. In the industrial area (Fig. 2B), samples taken from the sites located close to Bolesław Mining and Metallurgical Plants (sites 9-11) were distinguished by the highest $\mathrm{Pb}$ and $\mathrm{Zn}$ contents.

The mean density of the goldenrod at the study sites in the agricultural area was c. $45 \pm 18.3$ ramets $\mathrm{m}^{-2}$, while in the industrial area $-36 \pm 12.3$ ramets $\mathrm{m}^{-2}$; these values were statistically significant $(t=2.03, p=0.048, \mathrm{df}=48)$. The dry weight of aboveground and underground parts calculated per 1 ramet was given in Table 5. The average percentage contribution of individual morphological parts to the dry weight of SC harvested in agricultural and industrial areas was, respectively, as follows: roots, 12.7 and $8.7 \%$; the 
Table 1 Soil reaction, organic carbon and nitrogen content in soil samples collected in agricultural (AA) and industrial (IA) areas $(N=50)$

\begin{tabular}{|c|c|c|c|c|c|c|c|c|c|c|}
\hline \multirow[t]{2}{*}{ Parameter } & \multirow[t]{2}{*}{ Unit } & \multicolumn{4}{|l|}{ AA } & \multicolumn{4}{|l|}{ IA } & \multirow[t]{2}{*}{$\mathrm{M}-\mathrm{W}$ test value } \\
\hline & & Mean & Median & SD & Range & Mean & Median & SD & Range & \\
\hline Acidity & $\mathrm{pH}$ & 5.03 & 4.84 & 0.99 & $3.88-7.51$ & 6.51 & 6.53 & 0.77 & $5.00-7.75$ & $Z=4.49, p<0.001$ \\
\hline Corg & $\%$ & 1.66 & 1.54 & 0.47 & $1.03-2.64$ & 2.69 & 2.19 & 1.64 & $1.28-9.70$ & $Z=3.90, p<0.001$ \\
\hline $\mathrm{N}$ & $\mathrm{mg} / \mathrm{kg}$ & 1.01 & 0.91 & 0.28 & $0.63-1.79$ & 1.36 & 1.16 & 0.79 & $0.52-4.62$ & $Z=2.41, p=0.016$ \\
\hline
\end{tabular}

rhizomes, 28.5 and $25.9 \%$; the stems, 32.3 and $36.0 \%$; leaves, 13.5 and $15.8 \%$; flowers, 13.0 and $13.6 \%$. The above results and the results concerning the content of $\mathrm{Pb}$ and $\mathrm{Zn}$ in different morphological parts of the plant were used to calculate the content of metals in the underground ( $\mathrm{u}$ ) and aboveground (a) parts of SC per $\mathrm{m}^{2}$ (Fig. 3).

In the samples of goldenrod harvested in the industrial area, $\mathrm{Pb}$ accumulated in comparable amounts in the aboveground and underground parts of the plant, and in the industrial area the accumulation of $\mathrm{Pb}$ in the underground parts was more than seven times higher compared with the aboveground parts. On the other hand, the content of $\mathrm{Zn}$ in the aboveground parts of SC from the agricultural area was more than two times higher compared with the underground parts. In the industrial area, the zinc content in the above- and underground samples of goldenrod was similar (Fig. 3).

\section{Discussion}

The presented results of the research indicate that the content of $\mathrm{Pb}$ and $\mathrm{Zn}$ in the soil and different morphological parts of $S$. canadensis clearly varies depending on the location of the study sites. The $\mathrm{Pb}$ and $\mathrm{Zn}$ content for most of the analyzed soil samples collected in the agricultural area (Siedlce region) are within the range of values considered to be a natural content of these metals in light soils of Poland (Siebielec 2017), i.e., $50 \mathrm{mg} \mathrm{Pb} \mathrm{kg}^{-1}$ and $70 \mathrm{mg} \mathrm{Zn} \mathrm{kg}^{-1}$ (Kabata-Pendias et al. 1995). The industrial area (Olkusz region) is characterized by a much higher content of $\mathrm{Zn}$ and $\mathrm{Pb}$ due to natural deposits of $\mathrm{Zn}$ and $\mathrm{Pb}$ ores and related long-term mining and processing industry. Kapusta et al. (2015) reported the following content in the Olkusz ore-bearing region: $93-33,178 \mathrm{mg} \mathrm{Pb} \mathrm{kg}^{-1}$ and $132-72,089 \mathrm{mg} \mathrm{Zn} \mathrm{kg}^{-1}$ of soil. Gruszecka and Wdowin (2013) reported the average content of $\mathrm{Pb}$ and $\mathrm{Zn}$ in soil near Olkusz as $922 \mathrm{mg} \mathrm{Pb} \mathrm{kg}^{-1}$ and $694 \mathrm{mg} \mathrm{Zn} \mathrm{kg}^{-1}$. In our research, the highest content of $\mathrm{Pb}$ and $\mathrm{Zn}$ in the Olkusz region was recorded in samples collected from the sites located near Zakłady Górniczo-Hutnicze ZGH Bolesław (Bolesław Mining and Metallurgical Plants). This area is characterized by the highest level of soil contamination with $\mathrm{Pb}$ and $\mathrm{Zn}$ in the entire region (Gruszecka and Wdowin 2013; Kapusta et al. 2015). The range of $\mathrm{Pb}$ and $\mathrm{Zn}$ content in soil determined in our research does not differ significantly from the values reported in the literature. In both locations, the content of both metals in soil were significantly correlated.

The presence of SC in both locations, including sites heavily contaminated with $\mathrm{Pb}$ and $\mathrm{Zn}$, is consistent with literature data on the wide physiological tolerance of SC to environmental conditions (e.g., Jin et al. 2004; Huang et al. 2007)
Table 2 The content of $\mathrm{Pb}$ and $\mathrm{Zn}\left(\mathrm{mg} \mathrm{kg}^{-1}\right)$ in soil and morphological parts of Solidago canadensis at the sites in agricultural (AA) and industrial areas (IA). Significant differences in the same types of samples from both locations were checked with the Mann-Whitney (MW) test $(N=50)$. Indices a, b, c, d, e, and $\mathrm{f}$ show significant differences among different types of samples from each location checked with the Kruskal-Wallis test $(N=25, p<0.001)$ followed by Dunn's test. The value of the Kruskal-Wallis test $(p<0.0001)$ : $\mathrm{Pb}, \mathrm{AA}-\mathrm{H}_{5,150}=131.63$, $\mathrm{IA}-\mathrm{H}_{5,150}=130.88 ; \mathrm{Zn}: \mathrm{AA}-\mathrm{H}_{5,150}=67.00, \mathrm{IA}-\mathrm{H}_{5,150}=81.60$

\begin{tabular}{|c|c|c|c|c|c|c|c|c|c|c|}
\hline \multirow[t]{3}{*}{ Sample } & \multicolumn{5}{|l|}{$\mathrm{Pb}$} & \multicolumn{5}{|l|}{$\mathrm{Zn}$} \\
\hline & \multicolumn{2}{|l|}{$\mathrm{AA}$} & \multicolumn{2}{|l|}{ IA } & \multirow[t]{2}{*}{$\mathrm{M}-\mathrm{W}$ test $(Z ; p)$} & \multicolumn{2}{|l|}{$\mathrm{AA}$} & \multicolumn{2}{|l|}{ IA } & \multirow[t]{2}{*}{$\mathrm{M}-\mathrm{W}$ test $(Z ; p)$} \\
\hline & Median & Range & Median & Range & & Median & Range & Median & Range & \\
\hline Soil & $22.8^{\text {a,c,e }}$ & $17.4-40.2$ & $201.0^{\mathrm{a}, \mathrm{b}}$ & $69.5-1626.5$ & $6.05 ; p=0.000$ & $42.0^{\mathrm{a}, \mathrm{b}, \mathrm{c}, \mathrm{d}}$ & $11.2-125.9$ & $349.7^{\mathrm{a}, \mathrm{b}, \mathrm{e}}$ & $85.4-11626.1$ & $5.98 ; p=0.000$ \\
\hline Roots & $23.3^{\mathrm{b}, \mathrm{e}}$ & $19.2-27.8$ & $83.4^{\mathrm{a}, \mathrm{b}}$ & $38.5-789.5$ & $6.02 ; p=0.000$ & $28.9^{\mathrm{a}, \mathrm{b}, \mathrm{c}}$ & $2.9-343.5$ & $441.8^{\mathrm{a}, \mathrm{b}}$ & $221.1-2227.0$ & $5.87 ; p=0.000$ \\
\hline Rhizomes & $11.0^{\mathrm{a}, \mathrm{c}, \mathrm{f}}$ & $5.5-16.5$ & $27.0^{\mathrm{c}, \mathrm{e}}$ & $15.4-346.6$ & $5.39 ; p=0.000$ & $38.9^{\mathrm{a}, \mathrm{b}, \mathrm{c}, \mathrm{d}, \mathrm{e}}$ & $16.4-155.0$ & $140.3^{\mathrm{c}, \mathrm{d}, \mathrm{e}}$ & $39.5-2163.8$ & $4.81 ; p=0.000$ \\
\hline Stems & $5.75^{\mathrm{d}, \mathrm{f}}$ & $4.4-7.7$ & $9.2^{\mathrm{d}, \mathrm{f}}$ & $7.7-23.9$ & $3.26 ; p=0.001$ & $85.8^{\mathrm{a}, \mathrm{c}, \mathrm{d}, \mathrm{e}}$ & $19.5-489.2$ & $106.4^{\mathrm{c}, \mathrm{d}, \mathrm{e}}$ & $36.0-431.2$ & ns \\
\hline Leaves & $18.9^{\mathrm{a}, \mathrm{b}, \mathrm{e}}$ & $12.4-21.1$ & $32.5^{\mathrm{c}, \mathrm{e}}$ & $25.9-55.8$ & $5.18 ; p=0.000$ & $66.9^{\mathrm{c}, \mathrm{d}, \mathrm{e}}$ & $26.5-492.0$ & $164.4^{\mathrm{a}, \mathrm{c}, \mathrm{d}, \mathrm{e}}$ & $48.2-969.8$ & $2.73 ; p=0.006$ \\
\hline Inflorescences & $7.2^{\mathrm{c}, \mathrm{d}, \mathrm{f}}$ & $5.3-8.9$ & $13.0^{\mathrm{d}, \mathrm{f}}$ & $10.1-22.1$ & $5.66 ; p=0.000$ & $19.0^{\mathrm{f}}$ & $12.4-35.3$ & $45.2^{\mathrm{f}}$ & $29.2-332.0$ & $5.98 ; p=0.000$ \\
\hline
\end{tabular}

$n s$, not significant 
Table 3 Significant Spearman's rank correlation coefficients between $\mathrm{Pb}$ and $\mathrm{Zn}$ in the soil samples and morphological parts of Solidago canadensis in the agricultural and industrial areas; abbreviations in table: S, soil; R, roots; Rh, rhizomes; St, stems; L, leaves; I, inflorescences. Significant results are in bold $\left(* p<0.05,{ }^{*} p<0.01\right.$, $* * * p<0.001)$

\begin{tabular}{|c|c|c|c|c|c|c|c|c|c|c|c|c|}
\hline \multirow[t]{2}{*}{ Metal } & \multirow[t]{2}{*}{ Sample } & \multicolumn{6}{|l|}{$\mathrm{Pb}$} & \multicolumn{5}{|l|}{$\mathrm{Zn}$} \\
\hline & & S & $\mathrm{R}$ & $\mathrm{Rh}$ & St & $\mathrm{L}$ & I & S & $\mathrm{R}$ & $\mathrm{Rh}$ & St & $\mathrm{L}$ \\
\hline \multicolumn{13}{|c|}{ Agricultural area } \\
\hline \multirow[t]{6}{*}{$\mathrm{Pb}$} & $\mathrm{S}$ & - & & & & & & & & & & \\
\hline & $\mathrm{R}$ & -0.05 & - & & & & & & & & & \\
\hline & $\mathrm{Rh}$ & -0.05 & -0.26 & - & & & & & & & & \\
\hline & St & -0.04 & $-0.84^{* * *}$ & 0.28 & - & & & & & & & \\
\hline & $\mathrm{L}$ & -0.20 & 0.06 & 0.11 & 0.04 & - & & & & & & \\
\hline & I & $0.42 *$ & -0.17 & 0.30 & -0.02 & -0.32 & - & & & & & \\
\hline \multirow[t]{6}{*}{$\mathrm{Zn}$} & $\mathrm{S}$ & $0.92 * * *$ & - & & & & & - & & & & \\
\hline & $\mathrm{R}$ & -0.07 & 0.18 & - & & & & 0.14 & - & & & \\
\hline & $\mathrm{Rh}$ & -0.02 & -0.16 & 0.01 & - & & & -0.03 & $0.55^{* *}$ & - & & \\
\hline & St & 0.03 & -0.22 & 0.11 & -0.36 & - & & -0.01 & $0.45^{*}$ & $0.70 * * *$ & - & \\
\hline & $\mathrm{L}$ & -0.14 & $-0.42 *$ & 0.15 & -0.14 & -0.24 & - & -001 & 0.34 & $0.62 * * *$ & $0.67 * * *$ & - \\
\hline & I & 0.34 & -0.12 & -0.05 & -0.13 & 0.14 & -0.04 & -0.06 & 0.32 & $0.42 *$ & $0.42 *$ & $0.58 * *$ \\
\hline \multicolumn{13}{|c|}{ Industrial area } \\
\hline \multirow[t]{6}{*}{$\mathrm{Pb}$} & $\mathrm{S}$ & - & & & & & & & & & & \\
\hline & $\mathrm{R}$ & $0.60^{* * *}$ & - & & & & & & & & & \\
\hline & $\mathrm{Rh}$ & $0.43^{*}$ & $0.65^{* * * *}$ & - & & & & & & & & \\
\hline & $\mathrm{St}$ & $0.58^{* *}$ & 0.27 & 0.32 & - & & & & & & & \\
\hline & $\mathrm{L}$ & $0.51 * *$ & 0.11 & 0.19 & 0.33 & - & & & & & & \\
\hline & I & 0.39 & 0.11 & 0.34 & $0.50 *$ & 0.38 & - & & & & & \\
\hline \multirow[t]{6}{*}{$\mathrm{Zn}$} & $\mathrm{S}$ & $0.86^{* * * *}$ & - & & & & & - & & & & \\
\hline & $\mathrm{R}$ & $0.60 * *$ & $0.57 * *$ & - & & & & $0.58 * *$ & - & & & \\
\hline & $\mathrm{Rh}$ & 0.34 & $0.40^{*}$ & $\mathbf{0 . 7 0} * * * *$ & - & & & 0.38 & $0.66^{* * * *}$ & - & & \\
\hline & $\mathrm{St}$ & $0.52 * *$ & 0.25 & 0.39 & $0.56^{* * *}$ & - & & $0.42 *$ & $0.73 * * *$ & $0.70 * * *$ & - & \\
\hline & $\mathrm{L}$ & $0.67 * * *$ & 0.28 & 0.31 & $0.51 * *$ & 0.25 & - & $0.62 * * *$ & $0.64 * * *$ & $0.60 * *$ & $0.80 * * * *$ & - \\
\hline & I & $0.52 * *$ & 0.28 & 0.36 & $0.62 * *$ & 0.36 & $0.68 * * * *$ & $0.52 * *$ & $0.59 * *$ & $0.50 *$ & $0.68 * * * *$ & $0.73^{* * * *}$ \\
\hline
\end{tabular}

including the high content of heavy metals in soil (Huang et al. 2007; Yang et al. 2007b; Antonijevic et al. 2012; Xiang et al. 2010). Significant correlations between the concentration of contaminants in plant tissues and their concentration in the environment indicate the possible applicability of the plant

Table 4 Values of $\mathrm{Pb}$ and $\mathrm{Zn}$ bioconcentration $(\mathrm{BCF})$ and translocation (TF) factors calculated for samples collected in agricultural (AA) and industrial (IA) areas. Significant differences in the same types of as a biomonitor (Markert et al. 2003). In our study, significant correlations were determined between $\mathrm{Pb}$ and $\mathrm{Zn}$ content in different morphological parts of SC and the content of these metals in soil in the industrial area. However, no such relationships were found in the agricultural area. Based on the

samples from both locations were checked with the Mann-Whitney (MW) test $(N=50)$; abbreviations as in Table 3

\begin{tabular}{|c|c|c|c|c|c|c|c|}
\hline & \multirow[t]{2}{*}{ System } & \multicolumn{2}{|l|}{$\mathrm{Pb}$} & \multirow[t]{2}{*}{$\mathrm{M}-\mathrm{W}$ test $(Z ; p)$} & \multicolumn{2}{|l|}{$\mathrm{Zn}$} & \multirow[t]{2}{*}{$\mathrm{M}-\mathrm{W}$ test $(Z ; p)$} \\
\hline & & AA & IA & & AA & IA & \\
\hline $\mathrm{BCF}$ & $\mathrm{R} / \mathrm{S}$ & $1.01 \pm 0.21$ & $0.56 \pm 0.27$ & $Z=4.79 ; p<0.001$ & $1.24 \pm 1.43$ & $1.70 \pm 1.27$ & $Z=2.13 ; p<0.05$ \\
\hline \multirow[t]{4}{*}{$\mathrm{TF}$} & $\mathrm{Rh} / \mathrm{R}$ & $0.48 \pm 0.14$ & $0.35 \pm 0.15$ & $Z=2.05 ; p<0.01$ & $0.69 \pm 0.80$ & $0.31 \pm 0.19$ & $Z=5.86 ; p<0.001$ \\
\hline & $\mathrm{St} / \mathrm{R}$ & $0.26 \pm 0.06$ & $0.11 \pm 0.05$ & $Z=5.70 ; p<0.001$ & $4.14 \pm 4.21$ & $0.26 \pm 0.14$ & $Z=5.59 ; p<0.001$ \\
\hline & $\mathrm{L} / \mathrm{R}$ & $0.81 \pm 0.11$ & $0.39 \pm 0.22$ & $Z=5.30 ; p<0.001$ & $4.31 \pm 4.47$ & $0.37 \pm 0.19$ & $Z=3.32 ; p<0.001$ \\
\hline & $\mathrm{I} / \mathrm{R}$ & $0.32 \pm 0.04$ & $0.16 \pm 0.09$ & $Z=5.30 ; p<0.001$ & $0.81 \pm 0.84$ & $0.11 \pm 0.05$ & $Z=5.61 ; p<0.001$ \\
\hline
\end{tabular}




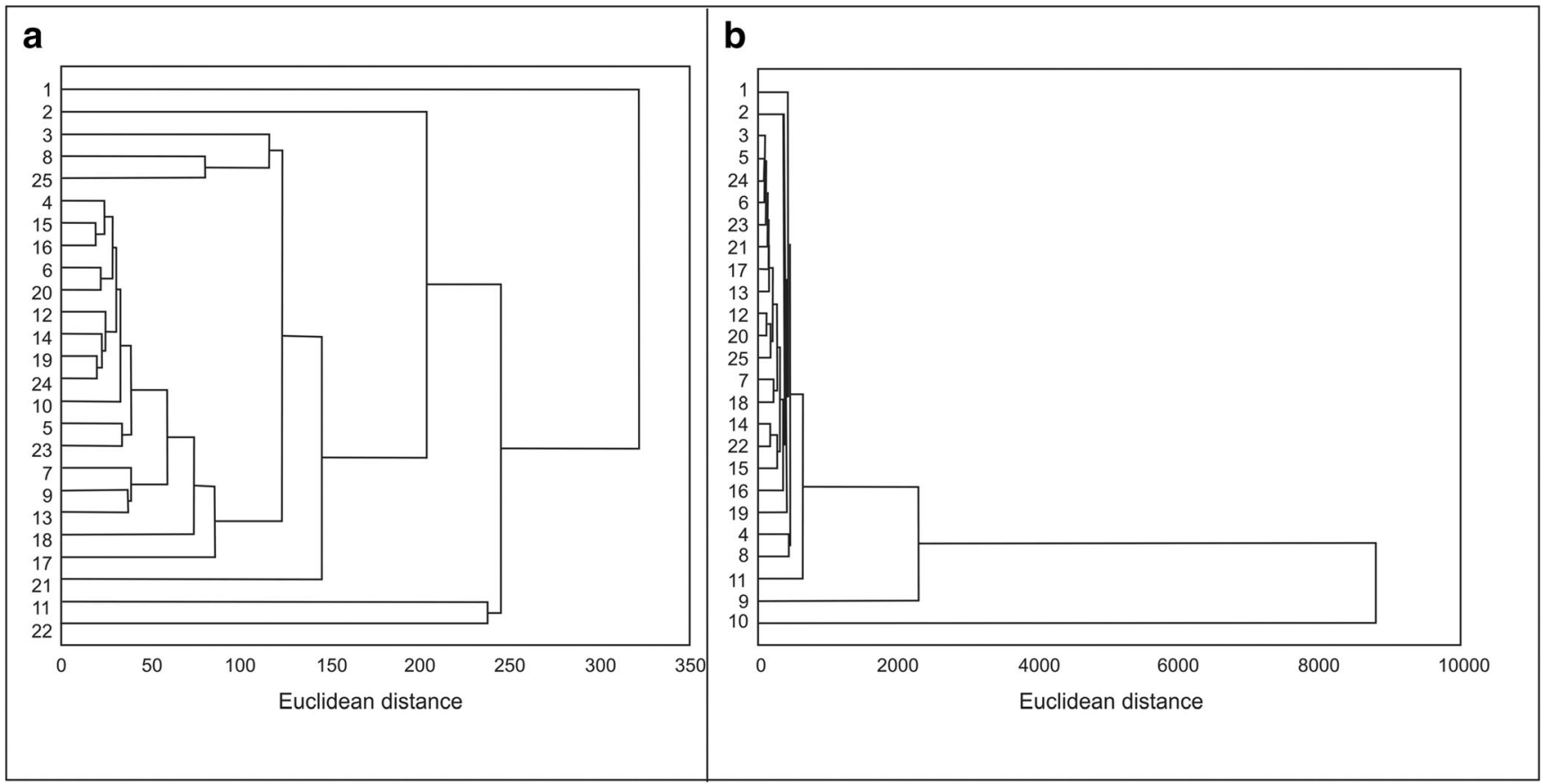

Fig. 2 Results of dendrological analysis presenting the similarity in the $\mathrm{Pb}$ and $\mathrm{Zn}$ content in soil and morphological parts of Solidago canadensis at the sites located in agricultural and in industrial areas

obtained data, it can be assumed that SC may serve as a bioaccumulator of $\mathrm{Pb}$ and $\mathrm{Zn}$ in a contaminated environment.

In both locations, roots of $S$. canadensis accumulate the largest amounts of $\mathrm{Pb}$ per unit mass. According to literature, in the environment with a high content of $\mathrm{Pb}$ in the soil, this element is accumulated mainly in the roots (Xiang et al. 2010), while $\mathrm{Zn}$, as a more mobile element compared with $\mathrm{Pb}$ (Vaněk et al. 2005), is transported to the aboveground plant parts. In plants, $\mathrm{Pb}$ uptake causes toxic effects resulting in decrease of biomass production (Gupta et al. 2013). Roots have the ability to absorb significant amounts of $\mathrm{Pb}$, while significantly reducing its translocation to the aboveground parts (Sharma and Dubey 2005). Lead which penetrates into the root symplast is detoxified in vacuoles, cell walls, and dictiosomal vesicles (Wierzbicka 1995). Limited translocation of $\mathrm{Pb}$ occurs from root to other parts due to the barrier function of the root endodermis (Sharma and Dubey 2005). Unlike lead, zinc plays a fundamental role in the functioning of plants, e.g., in maintenance of the integrity of cellular membranes, protein synthesis, and regulation of auxin. The metal plays a key role in both flower and normal fruit development (Hafeez et al. 2013).

The movement of metals from soil to plants is determined by specific soil properties, e.g., $\mathrm{pH}$, the content of organic matter and the content of nutrients (e.g., Takáč et al. 2009; Bini et al. 2012). Our results did not show a significant relationship between selected physicochemical properties of soil and the accumulation of $\mathrm{Pb}$ and $\mathrm{Zn}$ in SC tissues. The lack of impact of selected soil indicators on the accumulation of metals in the underground and aboveground parts of the SC may be the result of the impact of Solidago itself on the soil. The presence of goldenrod not only changes the chemical parameters of soil (Lu et al. 2005; Vanderhoeven et al. 2006; Zhang et al. 2009) but it also causes a decrease in soil

Table 5 Dry matter (mean, median, SD) of specific morphological parts calculated per 1 ramet of Solidago canadensis in agricultural (AA) and industrial (IA) areas $(N=50, \mathrm{df}=48)$

\begin{tabular}{|c|c|c|c|c|c|c|c|c|c|}
\hline \multirow[t]{2}{*}{ Part of the plant } & \multicolumn{4}{|l|}{ AA } & \multicolumn{4}{|l|}{ IA } & \multirow[t]{2}{*}{$t$ test value } \\
\hline & Mean & Median & $\mathrm{SD}$ & Range & Mean & Median & SD & Range & \\
\hline Inflorescences & 2.31 & 2.40 & 1.00 & $0.62-4.10$ & 2.49 & 2.45 & 0.69 & $1.60-4.35$ & $t=0.72, p=0.47$ \\
\hline Leaves & 2.38 & 2.23 & 0.90 & $0.76-4.30$ & 2.90 & 2.80 & 0.91 & $1.15-4.85$ & $t=2.07, p=0.04$ \\
\hline Stems & 5.70 & 5.25 & 2.57 & $1.36-11.5$ & 6.58 & 6.24 & 1.90 & $4.01-10.7$ & $t=1.38, p=0.17$ \\
\hline Rhizomes & 5.03 & 4.73 & 1.82 & $2.61-10.5$ & 4.74 & 4.75 & 2.65 & $1.56-12.7$ & $t=0.44, p=0.66$ \\
\hline Roots & 2.25 & 2.25 & 0.61 & $1.43-3.83$ & 1.59 & 1.49 & 0.74 & $0.64-3.17$ & $t=3.43, p=0.001$ \\
\hline
\end{tabular}


Fig. 3 Accumulation of $\mathrm{Pb}$ and $\mathrm{Zn}$ in underground (u) and aboveground (a) parts of Solidago canadensis per $\mathrm{m}^{2}$ in the two locations: agricultural (AA) and industrial (IA) areas

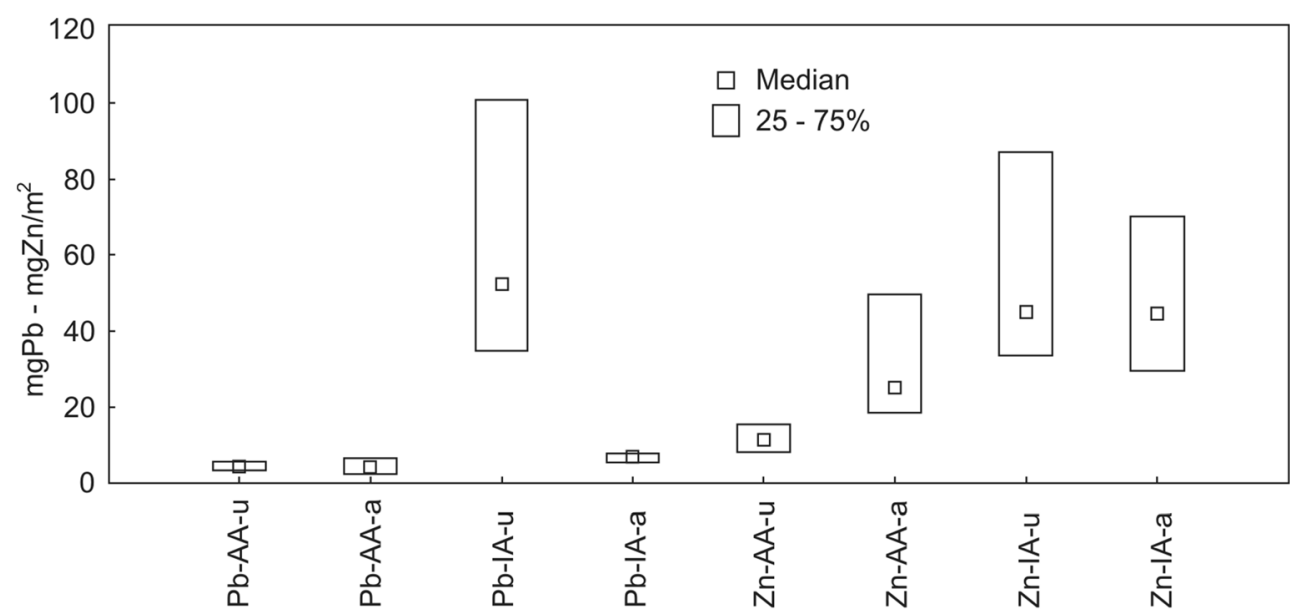

microbial activity (e.g., Zhang et al. 2009; Scharfy et al. 2010; Dong et al. 2015). A decrease in soil microbial activity also occurs in conditions of heavy soil contamination with heavy metals (Lee et al. 2002; Yang et al. 2007b). Under conditions of heavy soil contamination with heavy metals, metal accumulation in plant tissues decreases (Lee et al. 2002; Yang et al. $2007 \mathrm{~b})$. The results of our research indicate that the bioconcentration factor of $\mathrm{Pb}$ and translocation factor of $\mathrm{Pb}$ and $\mathrm{Zn}$ reach lower values in the environment with a higher content of metals in the soil. Similar relationships between the content of metals in soil contaminated with lead and zinc and their accumulation in plants were observed by Cook et al. (1994).

Based on the BCF and TF values, it is possible to assess the suitability of specific plant species for phytostabilization and phytoextraction (Ghosh and Singh 2005; Mleczek et al. 2017). The authors emphasize that plants with high BCF and low TF can be used for the phytostabilization of metals. In the case of $\mathrm{Pb}$, the $\mathrm{BCF}$ values were higher compared with the TF values in both locations. In the case of $\mathrm{Zn}$, the BCF values were higher compared with $\mathrm{TF}$ values in samples from the industrial area. It appears that SC can be used as a phytostabilizer of $\mathrm{Pb}$ and $\mathrm{Zn}$ in soils heavily contaminated with these metals.

In both locations, roots of $S$. canadensis accumulate the largest amounts of $\mathrm{Pb}$, which is particularly visible in the plant harvested in the contaminated area. In the industrial region, SC accumulates on average about $70 \mathrm{~g} \mathrm{~Pb} \mathrm{ha}^{-1}$ in the aboveground parts during the flowering season, and about $520 \mathrm{~g} \mathrm{~Pb}$ $\mathrm{ha}^{-1}$ in the underground parts. In the area with a natural content of $\mathrm{Pb}$ in the soil (agricultural area), the accumulation of $\mathrm{Pb}$ in the above- and underground parts is similar-about $40 \mathrm{~g} \mathrm{~Pb}$ $\mathrm{ha}^{-1}$ on average. Similar results concerning $\mathrm{Pb}$ accumulation in plants overgrowing old heaps associated with metallurgy industry received Stefanowicz et al. (2016). Plant species: $F$. vesca, $P$. arenaria, $P$. lanceolata, and $S$. ochroleuca, similarly as $S$. canadensis, accumulate the highest contents of $\mathrm{Pb}$ in the roots so they can be used in phytostabilization. Yang et al. (2008) point to the exceptionally high accumulation of
$\mathrm{Pb}$ in the underground parts of Solidago canadensis compared with the aboveground parts. Also, Xiang et al. (2010) emphasize the role of $\mathrm{SC}$ roots as a $\mathrm{Pb}$ accumulator and pay attention to the relatively high $(\mathrm{BCF}>1)$, compared with other metals, accumulation factor of $\mathrm{Pb}$.

The results of the conducted research indicate that $\mathrm{SC}$ can be used as a phytoremediator of $\mathrm{Zn}$ in particular. In the industrial area, its accumulation in the aboveground and underground parts of plants is similar and on average amounts to approximately $450 \mathrm{~g} \mathrm{Zn} \mathrm{ha}^{-1}$. In the area with a natural $\mathrm{Zn}$ content in the soil, this metal is accumulated in larger amounts (approximately $250 \mathrm{~g} \mathrm{ha}^{-1}$ on average) in the aboveground parts of SC compared with the underground parts (about $110 \mathrm{~g} \mathrm{ha}^{-1}$ on average).

Our results regarding the accumulation of $\mathrm{Pb}$ and $\mathrm{Zn}$ in $\mathrm{SC}$ biomass obtained from 1 ha are comparable with the values measured for other plant species used in phytoremediation (Sorghum biocolor, Helianthus annuus, Brassica juncea, Medicago sativa, Zea mays) which fall within ranges: $\mathrm{Pb}$, $16 \mathrm{~g} \mathrm{ha}^{-1}$ (H. annuus)-380 $\mathrm{g} \mathrm{ha}^{-1}$ (S. biocolor); Zn, $410 \mathrm{~g}$ $\mathrm{ha}^{-1}$ (H. annuus)-1410 $\mathrm{g} \mathrm{ha}^{-1}$ (S. biocolor) (Zhuang et al. 2009 and other authors cited in their paper).

Apart from the high content of zinc in the aboveground parts, additional traits that predispose the plant for phytoremediation are the high biomass (Patrzałek et al. 2012) and the occurrence in industrial areas (Vega et al. 2004; Antonijevic et al. 2012; Patrzałek et al. 2012). The removal of the aboveground biomass during the flowering period of the plant and its use as an energy source can be an effective method in the process of ecological restoration of zinc-contaminated areas.

\section{Conclusions}

The research on the accumulation of $\mathrm{Pb}$ and $\mathrm{Zn}$ in the aboveand underground parts of SC occurring in the uncontaminated environment and in the region affected by the mining and 
processing of $\mathrm{Pb}$ and $\mathrm{Zn}$ ores, hence characterized by an extremely high content of these elements in the soil, showed that $\mathrm{SC}$ can be used as:

- a bioaccumulator of lead and zinc content in the environment with increased content of $\mathrm{Pb}$ and $\mathrm{Zn}$ in the soil,

- a phytostabilizer of $\mathrm{Pb}$ and $\mathrm{Zn}$, mainly in contaminated soils. This is determined by the high accumulation of these metals in the underground parts of the plant,

- a phytoextractor of Zn-evidenced by a relatively high accumulation of this element in the aboveground parts of SC.

Open Access This article is distributed under the terms of the Creative Commons Attribution 4.0 International License (http:// creativecommons.org/licenses/by/4.0/), which permits unrestricted use, distribution, and reproduction in any medium, provided you give appropriate credit to the original author(s) and the source, provide a link to the Creative Commons license, and indicate if changes were made.

\section{References}

Antonijevic MM, Dimitrijevic MD, Milic SM, Nujki MM (2012) Metal concentrations in the soils and native plants surrounding the old flotation tailings pond of the Copper Mining and Smelting Complex Bor (Serbia). J Environ Monit 14:866-877. https://doi. org/10.1039/c2em10803h

Bini C, Wahsha M, Fontana S, Maleci L (2012) Effects of heavy metals on morphological characteristics of Taraxacum officinale web growing on mine soils in NE Italy. J Geochem Explor 123:101-108. https://doi.org/10.1016/j.gexplo.2012.07.009

Cheek MD, Semple JC (2016) First official record of naturalised populations of Solidago altissima L. var. pluricephala MC Johnst. (Asteraceae: Astereae) in Africa. S Afr J Bot 105:333-336. https:// doi.org/10.1016/j.sajb.2016.05.001

Cook CM, Sgardelis SP, Pantis JD, Lanaras T (1994) Concentrations of $\mathrm{Pb}, \mathrm{Zn}$ and $\mathrm{Cu}$ in Taraxacum spp. in relation to urban pollution. Bull Environ Contam Toxicol 53(2):204-210

Dong LJ, Sun ZK, Gao Y, He WM (2015) Two-year interactions between invasive Solidago canadensis and soil decrease its subsequent growth and competitive ability. J Plant Ecol 8:617-622

Fenesi A, Vágási CI, Beldean M, Földesi R, Kolcsár LP, Shapiro JT, Török E, Kovács-Hostyánszki A (2015) Solidago canadensis impacts on native plant and pollinator communities in different-aged old fields. Basic Appl Ecol 16:335-346. https://doi.org/10.1016/j. baae.2015.03.003

Ghosh M, Singh SP (2005) A review on phytoremediation of heavy metals and utilization of it's by products. As J Energy Env 3:1-18

Gioria M, Osborne BA (2014) Resource competition in plant invasions: emerging patterns and research needs. Front. Plant Sci 5:art501. https://doi.org/10.3389/fpls.2014.00501

Gruszecka AM, Wdowin M (2013) Characteristics and distribution of analyzed metals in soil profiles in the vicinity of a postflotation waste site in the Bukowno region, Poland. Environ Monit Assess 185:8157-8168. https://doi.org/10.1007/s10661-013-3164-9

Gupta DK, Huang HG, Corpas FJ (2013) Lead tolerance in plants: strategies for phytoremediation. Environ Sci Pollut Res 20:2150-2161. https://doi.org/10.1007/s11356-013-1485-4
Guzikowa M, Maycock PF (1986) The invasion and expansion of three North America species of goldenrod (Solidago canadensis L. sensu lato, S. gigantea Ait. and S. graminifolia (L.) Salisb.) in Poland. Acta Soc Bot Pol 55:367-384. https://doi.org/10.5586/asbp.1986. 034

Hafeez B, Khanif YM, Saleem (2013) Role of zinc in plant nutrition - a review. Am J Exp Agric 3:374-391. https://doi.org/10.9734/AJEA 2013/2746

Holeksa J, Błońska A, Kapała-Bąba A, Woźniak G, Kurek P, SzarekŁukaszewska G, Grodzińska K, Żywiec M (2015) The vegetation of the Olkusz ore-bearing region. In: Szafer W (ed) Institute of Botany, Natural and historical values of the Olkusz ore-bearing region. Polish Academy of Sciences, Kraków, pp 105-128

Hoser M, Pirowski A (2014) Ecophysiographic study of the city of Siedlce. Warsaw Development Planning Office, p 96

Huang H, Guo SL (2005) Analysis of population genetic differences of the invasive plant Solidago canadensis. Bull Bot Res 25(2):197-204

Huang H, Guo S, Chen G (2007) Reproductive biology in an invasive plant Solidago canadensis. Front Biol 2(2):196-204. https://doi.org/ 10.1007/s11515-007-0030-6

Jin L, Gu Y, Xiao M, Chen JK, Li B (2004) The history of Solidago canadensis invasion and the development of its mycorrhizal associations in newly-reclaimed land. Funct Plant Biol 31:979-986. https://doi.org/10.1071/FP04061

Kabata-Pendias A, Piotrowska M, Motowicka-Terelak T, MaliszewskaKordybach B, Filipiak K, Krakowiak A, Pietruch C (1995) Basics of chemical assessment of soil pollution. Heavy metals, sulfur and PAHs. Library of Environmental Monitoring, Warsaw p 29 (in Polish)

Kapusta P, Szarek-Łukaszewska G, Vogt RD (2015) Physicochemical and biological properties of soils in the prevailing types of plant communities in the Olkusz mining region. In: Godzik B (ed) W. Szafer Institute of Botany. Natural and historical values of the Olkusz ore-bearing region. Polish Academy of Sciences, Kraków

Laghlimi M, Baghdad B, El Hadi H, Bouabdli A (2015) Phytoremediation mechanisms of heavy metal contaminated soils: a review. Open J Ecol 5(8):5883210.4236/oje.2015.58031

Lee IS, Kim OK, Chang YY, Bae B, Kim HH, Baek KH (2002) Heavy metal concentrations and enzyme activities in soil from a contaminated Korean shooting range. J Biosci Bioeng 94(5):406-411

Lu JZ, Qiu W, Chen JK, Li B (2005) Impact of invasive species on soil properties: Canadian goldenrod (Solidago canadensis) as a case study. Biodivers Sci 13:347-356

Lu JZ, Weng ES, Wu XW, Weber E, Zhao B, Li B (2007) Potential distribution of Solidago canadensis in China. Acta Phytotaxon Sin 45:670-674. https://doi.org/10.1360/aps06200

Malik RN, Husain SH, Nazir I (2010) Heavy metals contamination in soil and wild plant species from industrial area of Islamabad, Pakistan. Pak J Bot 42(1):291-301

Marczenko Z (1979) Spectrophotometric determination of the elements. PWN, Warszawa (in Polish)

Markert B, Breure T, Zechmeister HG (2003) Definitions, strategies and principles for bioindication/biomonitoring of the environment. In: Markert BA, Breure AM, Zechmeister HG (eds) Bioindicators/ Biomonitors (principles, assessment, concepts). Elsevier, Amsterdam

Massa N, Andreucci F, Poli M, Aceto M, Barbato M, Berta G (2010) Screening for heavy metal accumulators amongst autochtonous plants in a polluted site in Italy. Ecotoxicol Environ Saf 73:19881997

Mleczek M, Goliński P, Krzesłowska M, Gąsecka M, Magdziak Z, Rutkowski P, Budzyńska S, Waliszewska B, Kozubik T, Karolewski Z, Niedzielski P (2017) Phytoextraction of potentially toxic elements by six tree species growing on hazardous mining sludge. Environ Sci Pollut Res 24:22183-22195. https://doi.org/ 10.1007/s11356-017-9842-3 
Ostrowska A, Gawliński S, Szczubiałka Z (1991) Methods of analysis and evaluation of soil and plant properties. Institute for Environmental Protection, Warsaw, p 334 (in Polish)

Patrzałek A, Kokowska-Pawłowska M, Nowińska K (2012) Use of goldenrod (Solidago sp.) from difficult habitats for energy purpose. Górnictwo i Geologia 7(2):177-185 (in Polish)

Scharfy D, Gusewell S, Gessner MO, Venterink HO (2010) Invasion of Solidago gigantea in contrasting experimental plant communities: effects on soil microbes, nutrients and plant-soil feedbacks. J Ecol 98:1379-1388. https://doi.org/10.1111/j.1365-2745.2010.01722.x

Semple JC, Rao KS (2017) Solidago altissima var. pluricephala (Asteraceae: Astereae) in India. Phytoneuron 32:1-6

Semple JC, Uesugi A (2017) Solidago altissima var. pluricephala (Asteraceae: Astereae) in Australia, Tonga, and Hawaii. Phytoneuron 40:1-16

Sharma P, Dubey RS (2005) Lead toxicity in plants. Braz J Plant Physiol 17:35-52. https://doi.org/10.1590/S1677-04202005000100004

Siebielec G (2017) Monitoring of chemistry of arable soils in Poland in 2015-2017. Institute for the Cultivation of Fertilization and Soil Science in Puławy, p 190 (in Polish)

Stefanowicz AM, Stanek M, Woch MW, Kapusta P (2016) The accumulation of elements in plants growing spontaneously on small heaps left by the historical $\mathrm{Zn}-\mathrm{Pb}$ ore mining. Environ Sci Pollut Res 23: 6524-6534. https://doi.org/10.1007/s11356-015-5859-7

Szymura M, Wolski K (2006) Landscape transformation in the influence of expansive North Americans perennial from Solidago L. genus. Regionalne Studia Ekologiczno-Krajobrazowe, Problemy Ekologii Krajobrazu 16(1):451-460 (in Polish)

Takáč P, Szabová T, Kozáková L, Benková M (2009) Heavy metals and their bioavailability from soils in the long-term polluted Central Spiš region of SR. Plant Soil Environ 55:167-172

Tokarska-Guzik B, Dajdok Z, Zając M, Urbisz A, Danielewicz W, Hołodyński C (2012) Alien plants in Poland with particular reference to invasive species, General Directorate for Environmental Protection, Warsaw, p 196 (in Polish, English summary)

Vanderhoeven S, Dassonville N, Chapuis-Lardy L, Hayez M, Meerts P (2006) Impact of the invasive alien plant Solidago gigantea on primary productivity, plant nutrient content and soil mineral nutrient concentrations. Plant Soil 286:259-268. https://doi.org/10.1007/ s11104-006-9042-2

Vaněk A, Borůvka L, Drábek O, Mihaljevič M, Komárek M (2005) Mobility of lead, zinc and cadmium in alluvial soils heavily polluted by smelting industry. Plant Soil Environ 51(7):316-321

Vega FA, Covelo EF, Andrade ML, Marcet P (2004) Relationships between heavy metals content and soil properties in minesoils. Anal Chim Acta 524:141-150. https://doi.org/10.1016/j.aca.2004.06.073
Wach J, Wach M, Ścisłowski M (2014) Ecophysiographic conditions of the city and commune of Olkusz. Service company "Geograf". Dąbrowa Górnicza p 43 (in Polish)

Wang C, Zhou J, Liu J, Wang L, Xiao H (2017) Reproductive allocation strategy of two herbaceous invasive plants across different cover classes. Pol J Environ Stud 26(1):355-364. https://doi.org/10. 15244/pjoes/64240

Weber E (1997) Morphological variation of the introduced perennial Solidago canadensis L. sensu lato (Astraceae) in Europe. Bot J Linn Soc 123:197-210. https://doi.org/10.1111/j.1095-8339.1997. tb01413.x

Weber E (2000) Biological flora of central Europe: Solidago altissima L. Flora 195:123-134. https://doi.org/10.1016/S0367-2530(17)30960$\mathrm{X}$

Weber E, Jacobs G (2005) Biological flora of central Europe: Solidago gigantea Aiton. Flora 200:109-118. https://doi.org/10.1016/j.flora. 2004.09.001

Weber E, Schmid B (1998) Latitudinal population differentiation in two species of Solidago (Asteraceae) introduced into Europe. Am J Bot 85(8):1110-1121. https://doi.org/10.2307/2446344

Wierzbicka M (1995) How lead loses its toxicity to plants. Acta Soc Bot Pol 64:81-90

Xiang YC, Feng T, Liu BG, Li HG, Chen Y (2010) Growth and accumulation character of heavy metals for Solidago canadensis grown in amended manganese mining tailing. Miner Eng Res 25(1):63-68

Yang RY, Tang JJ, Yang YS, Chen X (2007a) Invasive and non-invasive plants differ in response to soil heavy metal lead contamination. Bot Stud 48:453-458

Yang R, Tang J, Chen X, Hu S (2007b) Effects of coexisting plant species on soil microbes and soil enzymes in metal lead contaminated soils. Appl Soil Ecol 37:240-246. https://doi.org/10.1016/j.apsoil.2007. 07.004

Yang RY, Yu GD, Tang JJ, Chen X (2008) Effects of metal lead on growth and mycorrhizae of an invasive plant species (Solidago canadensis L.). J Environ Sci 20:739-744. https://doi.org/10.1016/S10010742(08)62121-X

Zhang CB, Wang J, Qian BY, Li WH (2009) Effects of the invader Solidago canadensis on soil properties. Appl Soil Ecol 43:163169. https://doi.org/10.1016/j.apsoil.2009.07.001

Zhuang P, Shu W, Li Z, Liao B, Li J, Shao J (2009) Removal of metals by sorghum plants from contaminated land. J Environ Sci 21(10): 1432-1437. https://doi.org/10.1016/S1001-0742(08)62436-5

Publisher's note Springer Nature remains neutral with regard to jurisdictional claims in published maps and institutional affiliations. 